\title{
Correction to: Scalar Effects in Ground Slate Technology and the Adaptive Consequences for Circumpolar Maritime Hunter-Gatherers
}

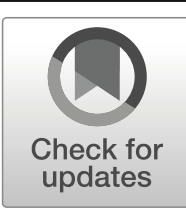

\section{Erlend Kirkeng Jørgensen ${ }^{1}$}

Published online: 16 June 2020

(C) Springer Science+Business Media, LLC, part of Springer Nature 2020

\section{Correction to: Journal of Archaeological Method and Theory https://doi.org/10.1007/s10816-020-09458-7}

Due to typesetting mistakes, the images of Figs. 1 and 10 contained errors. The site locations in the form of red and black dots were missing in Fig. 1, while the position of Fig. 10 was incorrect.

The original version has been corrected.

Publisher's Note Springer Nature remains neutral with regard to jurisdictional claims in published maps and institutional affiliations.

The online version of the original article can be found at https://doi.org/10.1007/s10816-020-09458-7

Erlend Kirkeng Jørgensen erlend.k.jorgensen@uit.no

1 Department of Archaeology, History, Religious Studies and Theology, UiT - The Arctic University of Norway, Langnes, Post box 6050, 9037 Tromsø, Norway 